УДК 81.112 .2

\title{
Л.А. Мишина
}

\section{ТЕКСТЫ Э.Т.А. ГОФМАНА КАК ХУДОЖЕСТВЕННЫЕ ПУТЕВОДИТЕЛИ}

В данной статье выявляются географические реалии и определяются их роли в романе немецкого романтика Э.Т.А. Гофмана «Эликсиры сатаны» и его новелле «Игнац Деннер». Прослежено воплощение в произведениях таких понятий гуманитарной географии, как география пространства, география пути, феномен путешественника.

Ключевые слова: Э.Т.А. Гофман, образная география, географический образ Германии, географический образ Италии.

DOI: $10.35634 / 2412-9534-2019-29-5-848-852$

Современное литературоведение расширяет границы исследования, делая предметом анализа представленный в художественном пространстве несобственно литературный материал: исторический, культурологический, страноведческий, географический. Каждый из этих аспектов является органической частью целого и в то же время сохраняет определенную автономность. Так, описание особенностей местности может служить средством создания характеров, обстановки, выражать эстетические воззрения автора и в то же время быть значимым как фактический материал. Географические подробности могут иметь место в произведениях, созданных в русле разных художественных направлений.

Немецкий романтик Эрнст Теодор Амадей Гофман (1776-1822), в соответствии с эстетикой художественного направления, стремился показать не обычное, а исключительное; не бытовое, а возвышенное. «Романтики, может быть совершенно неосознанно, воспроизводили в своих произведениях космический диалог между духом и бытием» [3. С. 35]. Теоретически бытие мыслилось как общечеловеческая категория, но в художественных произведениях это понятие приобретало национальную форму. Тексты Гофмана могут быть прочтены как своеобразные путеводители по Германии и близкой его сердцу Италии. Выявление в произведениях Гофмана географических образов и является целью данного исследования.

Нельзя не согласиться с мнением немецкого исследователя Й. Вэле о том, что история (шире реальность) является для Гофмана только декором [15. С. 13]. Однако даже в самых загадочных сочинениях Гофмана «декор» отличается точностью воспроизведения деталей. Таков роман «Эликсиры сатаны» (1815-1816) и писавшаяся одновременно с первой частью романа новелла «Игнац Деннер», опубликованная в 1815 г. в IV томе «Фантазий в манере Калло».

В новелле писатель не называет время действия - «в старое, давно прошедшее время» [2. С. 288], - но точно указывает место действия - округ Фульда. Впоследствии географическое положение места действия конкретизируется: становится известно, что ближайшим большим городом является Франкфурт, а близко к лесу подходят горы [2. С. 290, 293]. В этой обстановке развертывается причудливый сюжет о егере Андрее и его семье.

Роман «Эликсиры сатаны» посвящен духовным и психологическим исканиям монаха Медарда. Автора прежде всего интересует «путешествие» героя в глубины крайне запутанной истории его рода. Роман может быть сведен к притче о поисках истины и самого себя. В соответствии с притчевым началом персонажи возникают «ниоткуда», однако уже в конце первого абзаца происходит конкретизация - родители рассказчика совершают паломничество «в монастырь Святой Липы, что в далекой студеной Пруссии» [1. С. 7]. Топографическая и хронологическая точность логика более не покидают страниц романа. Любой момент повествования имеет свой хронотоп.

Определениями «далекая» и «студеная» рассказчик дистанцируется от указанного места действия, и впоследствии действительно становится ясно, что бо́льшая часть его жизни прошла в теплых, удаленных от Пруссии краях. Монастырь Святой Липы существовал в реальности и находился в Восточной Пруссии недалеко от Кёнигсберга, «оставаясь еще во времена Гофмана местом паломничества» [13. С. 510]. Как известно, Гофман родился и прожил первые двадцать лет жизни в Кёнигсберге. 
В свое время герой романа вместе с матерью возвращается из «далекой студеной Пруссии» на родину, в Южную Германию. Вре́менная остановка в предместьях Бамберга оказывается для Медарда судьбоносной: он знакомится с монастырем бернардинок, обучается в духовной семинарии Бамберга и навсегда остается в монастыре капуцинов, приняв постриг. В содержании романа отражены многие жизненные впечатления, которые писатель получил в бамбергский период (1808-1813). «Здесь он познакомился с духом и атмосферой монастырской жизни, а также с широко представленным в Бамберге после секуляризации типом бывшего монаха, что помогло ему создать эмоциональный фон «Эликсиров сатаны» [14. С. 178].

Южная Германия воспринимается Гофманом в отсвете Италии, находящейся сравнительно недалеко. В новелле «Игнац Деннер» Италия и Южная Германия рассматриваются разбойниками как один регион: банды, совершавшие здесь набеги, объединены и провозглашают одного короля. По ряду причин Медард, герой романа «Эликсиры сатаны», отправляется в Рим. Маршрут его путешествия намечает и обосновывает приор капуцианского монастыря Леонард. Герою кажется, что он идет по прямой, в направлении от монастыря, из ограниченного существования в большой мир, но, по замыслу писателя, это дорога, замкнутая кругом - подобно блудному сыну, приняв множество страданий, Медард по прошествии времени возвращается в родной монастырь.

В географии пространства Гофмана прежде всего интересует география пути. В движении, в определенный период своей жизни, пребывает не только Медард, но большинство героев романа. Формы движения различны: это паломничество, бегство, странствия, путешествия, деловой вояж, скитания, бытовая поездка, возвращение домой. Географически роман представляет собой густую сеть маршрутов, которые в назначенных автором точках пересекаются.

Путешествие Медарда из Бамберга в Рим представлено в таких географических и бытовых подробностях, что его не трудно воспроизвести графически; подробно описан и рельеф местности. Писатели и поэты преуспели в воссоздании ландшафтов. Особое значение пейзаж приобрел в произведениях романтиков, которые ввели в литературу фольклорный прием «параллелизм состояния человека и природы». Этот прием позволял не только глубже проанализировать психологическое состояние героев, но и создать выразительные пейзажные зарисовки. Покинувший монастырь Медард созерцает живописную местность: «Глубоко в долине сквозь голубую дымку виднелся монастырь... Уже несколько дней скитался я среди чудовищных нагромождений скал, между которыми вилась узкая тропа, а глубоко внизу бушевали окаймленные лесом потоки... Я свернул на узенькую тропинку, извивающуюся по крутому склону, и, выйдя из кустов, увидел в глубине долины прекрасный величественный замок...» [1. С. 36, 37, 39]. Словесные пейзажи созданы Гофманом с натуры - для Южной Германии действительно характерен подобный рельеф.

Медард не раз замечает, что он пробивается сквозь чащу леса [1. С. 66] или «продирается сквозь пихтовый, стеною стоящий лес» [1. С. 65]. Покрытые лесами горы географы считают особенностью этого региона Германии. Гофман точен даже в обозначении породы деревьев - пихты, наряду с елями и буками, составляют основу лесного массива Баварских Альп.

Гофман, в большинстве своих произведений выступающий как урбанист, в романе «Эликсиры сатаны» открывает лес и обнаруживает в нем не меньшую многоликость и духовность, чем в городской жизни. «...А когда вокруг шелест и шепот, - рассказывает Медарду встреченный им на пути лесничий, - то иной раз приходит на ум, будто деревья хотят что-то сказать мне на своем особенном языке...» [1. С. 89]. Лес самодостаточен и автономен, он живет по своим собственным законам. Лес является одним из основных понятий немецкого образа мира. Сюжет многих немецких народных сказок и литературных произведений развертывается в лесу. В 1813 г. в Касселе братья Гримм издали двухтомник «Старонемецкие леса», в котором собраны произведения немецкого фольклора и немецкой поэзии на тему леса.

Лес является основным местом действия в новелле «Игнац Деннер». Здесь он лишен романтического ореола и характеризуется автором настойчиво повторяющимися словосочетаниями «дикий, огромный лес», «далекий дикий лес», «темный пустынный лес», «лес безлюден», «черные сосны» [2. С. $289,290,292,295,296]$; в лесу обитают волки и дикие свиньи. Несмотря на мрачный колорит, описание соответствует действительности: лес в этой части Германии по преимуществу сосновый, и в нем наблюдается популяция волков и кабанов.

Осознавая, что созерцает «живописные, романтические места» [1. С. 139], Медард в романе «Эликсиры сатаны» не имеет возможности на этом сосредоточиться, так как авторский замысел уго- 
товил ему иное. Однако, несмотря на сложнейшие жизненные перипетии, с дистанции он не сходит. Обозначение маршрута - на юг, вперед по прямой - представляет собой остов, позвоночник, на котором держится тирада Медарда: «Не зная отдыха, я мчался по прекрасной местности и нигде не находил покоя - так неудержимо влекло меня все дальше на юг; сам того не замечая, я до сих пор лишь незначительно уклонялся от пути, начертанного мне приором, и, таким образом, толчок, который он мне сообщил... побуждал меня... двигаться вперед по прямой» [1. С. 86]. Путешествующий герой интересен художнику тем, что, по мнению Д.Н. Замятина, «во время путешествия происходит расширение сознания, обострение всех чувств» [5. С. 223]. Продуктивной в процессе анализа художественного текста является также мысль ученого о том, что «движение путешественника происходит одновременно в реальном и образном пространствах» [5. С. 225].

Гофман не фиксирует момент пересечения Медардом границы Италии, более того, герой в это время находится в бессознательном состоянии. Тем ярче перед ним, пришедшим в себя, предстает Италия. Монах, который выхаживает больного Медарда, распахнул окно, и Италия как будто ворвалась в жизнь героя: «...Теплый дивный воздух, каким мне еще не приходилось дышать, хлынул в комнату; к зданию больницы примыкал сад, где зеленели прекрасные деревья, покрытые цветами, а вся стена была увита пышными лозами винограда, - вспоминает Медард, - Но больше всего меня поразило темно-синее благоуханное небо...» [1. С. 182]. Ключевыми словами в этом пассаже являются: «теплый дивный воздух», «деревья, покрытые цветами», «темно-синее благоуханное небо».

В итальянские сцены писатель, безусловно, вложил свое представление об этой столь любимой, но ни разу не увиденной им стране. Интерес Гофмана к Италии отмечен исследователями. Рассуждая о художественном пространстве произведений писателя, Н.А. Жирмунская пишет, что «нередко это пространство предстает в виде двух контрастных планов, географически удаленных друг от друга, двух культурно-психологических зон - Германии и Италии» [4. С. 14]. Заветной мечтой Италия стала уже для немецких гуманистов. Первыми из них были учениками итальянцев; поездка в Италию, приобщение к ее культуре считались обязательными компонентами программы каждого деятеля эпоха Возрождения. Представление Гофмана об Италии зиждилось не только на сугубо личном восприятии, но и на знаниях о стране - ее природе, климате, быте, культуре, религии. Именно так рождается географический образ, который представляет собой систему «взаимосвязанных и взаимодействующих знаков, символов, архетипов и стереотипов, ярко и в то же время достаточно просто характеризующих какую-либо территорию (место, ландшафт, регион, страну)» [6. С. 29].

Страноведческий материал об Италии в романе достаточно скуп: он ограничен перечислением главных соборов Рима, описанием посещения Ватикана и кукольного спектакля на площади Испании. Возможно, это связано с тем, что прямая дорога, по которой Медард продвигался из Германии в Рим, уже изменила траекторию и устремилась к началу, чтобы в свое время превратиться в круг. Географически Медард возвращается в родной монастырь «той же самой тропой», которой шел в Рим. Но психологически это совсем другая дорога. Путь из дома в большой мир и путь из большого мира домой трактуются как принципиально разные понятия. Путь из дома связан с романтическим стремлением вырваться из замкнутого пространства, путь домой продиктован осознанием ценности дома, приюта. В маршруте Медарда те же основные пункты, которые встречались по направлению к Риму, но многолетний путь герой на этот раз преодолевает за несколько недель.

Итальянский пласт является важнейшей составляющей в новелле «Игнац Деннер». Обозначив место действия - немецкий округ Фульда, повествователь далее рассказывает историю, развернувшуюся в Италии, где в одной из неаполитанских гостиниц герой новеллы немец Андрес встретил свою возлюбленную, итальянку Джорджину, и увез ее в Германию. «Холодная Германия» и «прекрасная Италия» оказываются связанными многочисленными нитями. Конфликты, возникшие в далекие времена в Италии, получают свое драматическое продолжение и разрешение в Германии.

История доктора Трабаккио, являясь новеллой в новелле, дает возможность Гофману полностью погрузиться в итальянский материал. Таинственный ореол вокруг личности чудо-доктора Трабаккио, описание его дома, упоминание итальянских названий, например, яда «аква Тоффана», создают итальянский колорит. Новелла, как нам представляется, дает возможность расширить традиционный перечень причин, по которым писатель интересовался Италией. Гофману как романтику были важны исключительные характеры: яркие красавицы, колдуны, разбойники. Примечательно, однако, что сын Трабаккио бежит из Италии в Швейцарию, где принимает имя Игнаца Деннера. А если бы новелла была опубликована в первой редакции, то связь Германии и Италии оказалась бы еще теснее: 
сын Андреса отправился в Италию, где «под именем Джорджио Андрейно он стал знаменитым певцом и композитором и блистал в театрах Рима и Неаполя [8. С. 519].

В рамках данной статьи роман Э.Т.А Гофмана «Эликсиры сатаны» и новелла «Игнац Деннер» рассмотрены с географической точки зрения. В исследовании прослежено воплощение в произведении таких понятий, как география пространства, география пути, феномен путешественника, особенности географических образов Германии и Италии. Сочинения изобилуют географическими реалиями и могут, в определенной степени, трактоваться как источник информации об одном из регионов Западной Европы. В то же время отношение к природе является для Гофмана способом создания характеров. Художественное и научное сознание удачно дополняют друг друга.

Географический анализ произведений Гофмана может быть продолжен. Новеллы и повести писателя представляют собой благодатный материал для изучения немецкого и - шире - европейского образов мира, сложившихся в первой четверти XIX в. О перспективности исследований такого рода свидетельствуют работы Е.Н. Перцика «География и искусство» [11], Р.А. Пименовой «Географические образы в музыкальном искусстве» [12], Л.Е. Перлова «География в литературных произведенияХ» [10], В.П. Максаковского «Литературная география» [9], В.Н. Калуцкова «Ландшафт в культурной географии» [7].

\section{СПИСОК ЛИТЕРАТУРЫ}

1. Гофман Э.Т.А. Эликсиры сатаны. Пер. Н. Славятинского// Э.Т.А. Гофман. Эликсиры сатаны. Ночные рассказы. М., 1992. С. 5-256.

2. Гофман Э.Т.А. Игнац Деннер. Пер. неизвестен // Э.Т.А. Гофман. Эликсиры сатаны. Ночные рассказы. Цит. изд. С. 288-330.

3. Грешных В.И. Мистерия духа. Художественная проза немецких романтиков. Калининград, 2001. 406 с.

4. Жирмунская Н.А. Новеллы Э.Т.А. Гофмана в сегодняшнем мире // Э.Т.А. Гофман. Новеллы. Л., 1990. С. 3-21.

5. Замятин Д.Н. Геокультура и процессы межцивилизационной адаптации: стратегии репрезентации и интерпретации ключевых культурно-географических образов // Цивилизация. Восхождение и слом. М., 2003. C. $222-234$.

6. Замятин Д.Н. Гуманитарная география: пространство, воображение и взаимодействие гуманитарных наук // Социологическое обозрение. 2010. Т. 9, № 3. С. 26-50.

7. Калуцков В.Н. Ландшафт в культурной географии. М., 2008. 320 с.

8. Лагутина И.Н. Примечания // Э.Т.А. Гофман. Эликсиры сатаны. Ночные рассказы. Цит. изд. С. 518-519.

9. Максаковский В.П. Литературная география. М., 2006. 407 с

10. Перлов Л.Е. География в литературных произведениях. М., 2004. 222 с.

11. Перцик Е.Н. География и искусство // Экономическая и социальная география на пороге XXI века. М. Смоленск, 1997. С. 109-125.

12. Пименова Р.А. Географические образы в музыкальном искусстве. М., 2005. 63 с.

13. Примечания // Э.Т.А. Гофман. Эликсиры сатаны. Цит. изд. С. 509-516.

14. Сафрански Р. Гофман. М., 2005. 383 с.

15. Wele J. Vergangenheit als innere Welt: historische Erzählen bei E.T.A. Hoffmann. Fr-a.-Main, 1996. 328 s.

Поступила в редакцию 12.07.2019

Мишина Лариса Алексеевна

ГАОУ ВО города Москвы «Московский городской педагогический университет»

129226, Россия, г. Москва, 2-й Сельскохозяйственный проезд, 4

E-mail: fraumischina@yandex.ru

\section{L.A. Mishina \\ E.T.A. HOFFMANN'S TEXTS AS ART GUIDES}

DOI: 10.35634/2412-9534-2019-29-5-848-852

The goal of the article is to reveal the geographical realias and define their roles in the novel of the German romanticist E.T.A. Hoffmann "Devil's elixirs" and his story "Ignaz Denner". The embodiment of such ideas of humanitarian geography as geography of space, geography of way, phenomenon of traveler is traced.

Keywords: E.T.A. Hoffmann, image geography, geographical image of Germany, geographical image of Italy. 


\section{REFERENCES}

1. Gofman E.T.A. Eliksiry satany. Per. N. Slavyatinskogo// E.T.A. Gofman. Eliksiry satany. Nochnye rasskazy. M., 1992. S. 5-256.

2. Gofman E.T.A. Ignac Denner. Per.neizvesten // E.T.A. Gofman. Eliksiry satany. Nochnye rasskazy. Cit.izd. S. 288-330.

3. Greshnyh V.I. Misteriya duha. Hudozhestvennaya proza nemeckih romantikov. Kaliningrad, 2001. $406 \mathrm{~s}$.

4. ZHirmunskaya N.A. Novelly E.T.A. Gofmana v segodnyashnem mire // E.T.A. Gofman. Novelly. L., 1990. S. 3-21.

5. Zamyatin D.N. Geokul'tura i processy 1mezhcivilizacionnoj adaptacii: strategii reprezentacii i interpretacii klyuchevyh kul'turno-geograficheskih obrazov // Civilizaciya. Voskhozhdenie i slom. M., 2003. S. 222-234.

6. Zamyatin D.N. Gumanitarnaya geografiya: prostranstvo, voobrazhenie i vzaimodejstvie gumanitarnyh nauk // Sociologicheskoe obozrenie. 2010, T. 9. № 3. S. 26-50.

7. Kaluckov V.N. Landshaft v kul'turnoj geografii. M., 2008. 320 s.

8. Lagutina I.N. Primechaniya// E.T.A.Gofman. Eliksiry satany. Nochnye rasskazy. Cit. izd. S. 518-519.

9. Maksakovskij V.P. Literaturnaya geografiya. M., 2006. 407 s.

10. Perlov L.E. Geografiya v literaturnyh proizvedeniyah. M., 2004. 222 s.

11. Percik E.N. Geografiya i iskusstvo // Ekonomicheskaya i social'naya geografiya na poroge XXI veka. Moskva Smolensk, 1997. S. 109-125.

12. Pimenova R.A. Geograficheskie obrazy v muzykal'nom iskusstve. M., 2005. 63 s.

13. Primechaniya // E.T.A. Gofman. Eliksiry satany. Cit. izd. S. 509-516.

14. Safranski R. Gofman. M., 2005. 383 s.

15. Wele J. Vergangenheit als innere Welt: historische Erzählen bei E.T.A. Hoffmann. Fr-a.-Main, 1996. 328 s.

Mishina L.A.

Moscow City University

2-i Sel'skokhozyaistvennyi proezd, 4, Moscow, Russia, 129226

E-mail: fraumischina@yandex.ru 